\title{
Entrepreneurial Intentions and Entrepreneurial Motivation of South African Rural University Students
}

\author{
Mmakgabo Justice Malebana \\ Tshwane University of Technology, South Africa \\ malebanaj@webmail.co.za
}

\begin{abstract}
Entrepreneurial motivation is vital in translating entrepreneurial intention into action. This paper investigates whether entrepreneurial role models, social valuation of entrepreneurship, perceived knowledge of entrepreneurial support and barriers to starting a business, entrepreneurial intention and its determinants are related to entrepreneurial motivation. The study integrates the theory of planned behaviour with environmental factors to determine the factors influencing entrepreneurial motivation among final year rural university students in the Limpopo province, South Africa. The study was carried out by means of a survey and included 329 final year students who were registered for various commerce degrees. A structured questionnaire was used to collect the data. Data were analysed by means of descriptive statistics, Pearson correlation and hierarchical multiple regression analysis. The findings indicate that entrepreneurial motivation has a significant correlation with entrepreneurial intention and its three determinants, social valuation of entrepreneurship, having entrepreneurial role models, knowledge of entrepreneurial support and perceived barriers to starting a business. The respondents were motivated by both intrinsic and extrinsic rewards and the need for independence. The results revealed that entrepreneurial intention, the attitude towards becoming an entrepreneur, subjective norms, social valuation of entrepreneurship, knowledge of entrepreneurial role models and entrepreneurial support have a significant influence on entrepreneurial motivation. This study is the first in South Africa to use theory of planned behaviour to investigate the factors that influence entrepreneurial motivation. The study contributes to the body of knowledge by shedding light into the impact of the social environment on entrepreneurial motivation in South Africa.
\end{abstract}

Keywords: Barriers to starting a business, entrepreneurial support, theory of planned behaviour, social valuation of entrepreneurship, entrepreneurial role models

\section{Introduction}

The importance of entrepreneurship as a contributor to job creation, innovation and economic development is widely acknowledged (Sesen, 2013; Hopp \& Stephan, 2012; Nabi \& Liñán, 2011).Entrepreneurship is a field of study that examines 'how, by whom, and with what effects opportunities to create future goods and services are discovered, evaluated, and exploited' (Shane \& Venkataraman, 2000, p. 218). Entrepreneurial activity is dependent on entrepreneurs who recognise, evaluate and exploit opportunities (Ardichvili, Cardozo \& Ray, 2003; Shane, Locke \& Collins, 2003; Shane \& Venkataraman, 2000). A growing body of literature exists that suggests that intentions play a significant role in the decision to start a new business (for example, Schlaegel \& Koenig, 2014; Liñán, Nabi \& Krueger, 2013; Liñán \& Chen, 2009; Krueger, Reilly \& Carsrud, 2000; Bird, 1988). Researchers argue that entrepreneurial action follows the formation of entrepreneurial intention (Douglas, 2013; Shook, Priem \& McGee, 2003).This view is supported by Delanoë (2013); Zhang and Yang (2006) and Kolvereid and Isaksen (2006) who have found a positive relationship between entrepreneurial intentions and entrepreneurial behaviour.

Whilst the formation of entrepreneurial intention and the pursuit of the recognised opportunity are vital for entrepreneurial activity to occur (Nabi \& Liñán, 2011; Carsrud \& Brännback, 2011), entrepreneurial motivation is necessary to translate intentions into action that exploits these opportunities. Until individuals make attempts to translate their intentions into action such intentions will remain behavioural dispositions (Ajzen, 2005). Motivation entails internal factors that impel action and external factors that can act as inducements to action (Locke \& Latham, 2004). Entrepreneurial motivation impacts on entrepreneurial action through the choices made by individuals, and their efforts and persistence in the chosen activities. Individuals' motivations influence their decision to search, evaluate and exploit entrepreneurial opportunities, and differences in these motivations determine which 
individuals pursue these opportunities, assemble resources, and how they execute the entrepreneurial process (Shane et al., 2003). Kuratko and Hodgetts (2007) suggest that the effort exerted in creating a new venture and the willingness to sustain that venture is associated with an entrepreneur's motivation. Hence motivation is considered to be the link between intention and action (Carsrud \& Brännback, 2011). Previous research found that entrepreneurial motivation influence small business growth (Delmar \& Wiklund, 2008). On the other hand a significant relationship was found between entrepreneurial motivation and entrepreneurial intention (Solesvik, 2013; Achchuthan \& Nimalathasan, 2013).Carsrud and Brännback (2011) argue that there is a link between entrepreneurial intentions, motivation and behaviour but it is neither linear nor unidirectional. They indicated that since intentions do not translate immediately into action, 'motivation may be the spark that transforms a latent intention into real action and therefore, the missing link between intentions and action' (Carsrud \&Brännback, 2011, p. 12).

Both entrepreneurial intention and entrepreneurial motivation are shaped by personal and environmental factors. Entrepreneurial intention theory had shown that personal and environmental factors can affect entrepreneurial intention directly or indirectly by influencing beliefs and attitudes regarding entrepreneurship (Liñán et al., 2013; Achchuthan \& Nimalathasan, 2013; Liñán, Urbano \& Guerrero, 2011; Katono, Heintze \& Byabashaija, 2010; Liñán \& Chen, 2009; Boyd \& Vozikis, 1994).Entrepreneurial motivation is determined by entrepreneurs' perceptions of their environment and their own abilities (Estay, Durrieu \& Akhter, 2013), personal characteristics, the personal environment (Taormina \& Lao, 2007), the relevant business environment, the specific business idea, and the goals of the entrepreneur (Naffziger, Hornsby \& Kuratko, 1994). Aspects of the environment are therefore vital for entrepreneurship development (Gnyawali \& Fogel, 1994) and for shedding light into the determinants of entrepreneurial motivation.

Researchers have indicated that entrepreneurship is a social activity that is influenced by the social environment of individuals (Román, Congregado \& Millán, 2013; Sesen, 2013; Stephan \& Uhlaner, 2010). Therefore, entrepreneurial activity can be facilitated or hindered by certain socio-cultural practices, values and norms (Krueger, Liñán \& Nabi, 2013). The social environment impacts on entrepreneurial activity by contributing to the formation of positive attitudes towards entrepreneurship and enhanced perceived behavioural control which in turn influence entrepreneurial intention (Krueger \& Brazeal, 1994). This environment also stimulates entrepreneurial motivation. Stephan and Uhlaner (2010) found that a socially supportive culture is associated with entrepreneurial activity, higher entrepreneurial selfefficacy beliefs and social desirability of entrepreneurship. Countries with high regional social legitimacy of entrepreneurship encourage the formation of positive attitudes towards entrepreneurship (Kibler, Kautonen \& Fink, 2014). This study contributes to an understanding of entrepreneurial motivation by drawing from the view that entrepreneurial motivation links entrepreneurial intention with action (Fayolle, Liñán\& Moriano, 2014; Carsrud \&Brännback, 2011). This is also supported by the fact that entrepreneurial motivation influences small business growth (Delmar \& Wiklund, 2008). Since entrepreneurial motivation can explain and predict entrepreneurial behaviour (Carsrud \&Brännback, 2011), it is vital for policymakers to consider personal and environmental factors that affect entrepreneurial motivation so that the impact of their policies and programmes could be maximised. Equipped with knowledge of these factors, policymakers will be able to create an environment that 'has the potential for increasing entrepreneurial activity' (Krueger \& Brazeal, 1994, p. 92). The study builds on entrepreneurial intention and motivation theories to determine the influence of personal and environmental factors on entrepreneurial motivation.

Prior research found that entrepreneurial role models, social and closer valuation of entrepreneurship, and knowledge of available entrepreneurial support are associated with entrepreneurial intention and its determinants (Malebana, 2014a; Solesvik, 2013; Liñán et al., 2013; Uygun \& Kasimoglu, 2012; Liñán et al., 2011; Liñán\& Chen 2009;Liñán, 2008). It has not yet been established whether these factors are related to the motivation to start a business, except for role models (Rahman\& Day, 2013). A number of studies have also investigated entrepreneurial motivation and barriers to starting a new venture (for example Giacomin, Janssen, Pruett, Shinnar, Llopis \& Toney, 2011; Smith \& Beasley, 2011; Katono et al., 2010; Liang \& Dunn, 2007; Choo \& Wong, 2006).However, they have not linked these factors to entrepreneurial intention and its theoretical determinants. Specifically, this study attempts to fill the gap concerning the lack of knowledge regarding whether entrepreneurial role models, social valuation of entrepreneurship, perceived knowledge of entrepreneurial support and barriers to starting a business, entrepreneurial intention and its determinants influence entrepreneurial motivation. The study extends the entrepreneurial motivation theory through an integrated view of entrepreneurial motivation that draws 
from the theory of planned behaviour and the role of environmental factors to determine factors that influence entrepreneurial motivation. The purpose of the study was to identify the motives for starting a business among rural university students in South Africa and to establish whether the determinants of entrepreneurial intention and entrepreneurial intention, knowledge of entrepreneurial role models, social valuation of entrepreneurship, knowledge of entrepreneurial support and perceived barriers to starting a business are associated with entrepreneurial motivation. An understanding of the motivations of final year students and the factors influencing them would help policymakers in designing relevant programmes for entrepreneurship development, especially those directed at stimulating youth entrepreneurship in the rural areas of South Africa. An understanding of the factors impacting on entrepreneurial motivation is vital in increasing the number of potential entrepreneurs with the motivation and the ability to identify, evaluate and exploit new business opportunities, particularly in the efforts to raise South Africa's low total entrepreneurial activity (TEA) rates (Herrington \& Kelley, 2013; Herrington \& Kew, 2014).

\section{Literature Review}

Determinants of entrepreneurial motivation: As already explained, this study is based on the premise that entrepreneurial motivation is a link between entrepreneurial intention and action. Therefore, the theory of planned behaviour is used to explore the influence of the determinants of entrepreneurial intention and entrepreneurial intention on entrepreneurial motivation. In addition, entrepreneurial motivation can also be shaped by certain environmental aspects which include exposure to entrepreneurial role models, social valuation of entrepreneurship, knowledge of available entrepreneurial support and perceived barriers to starting a business (Figure 1). The study seeks to determine the effect of these factors on entrepreneurial motivation. The discussion in the next section focuses on the role of these factors in determining the motivation to start a business.

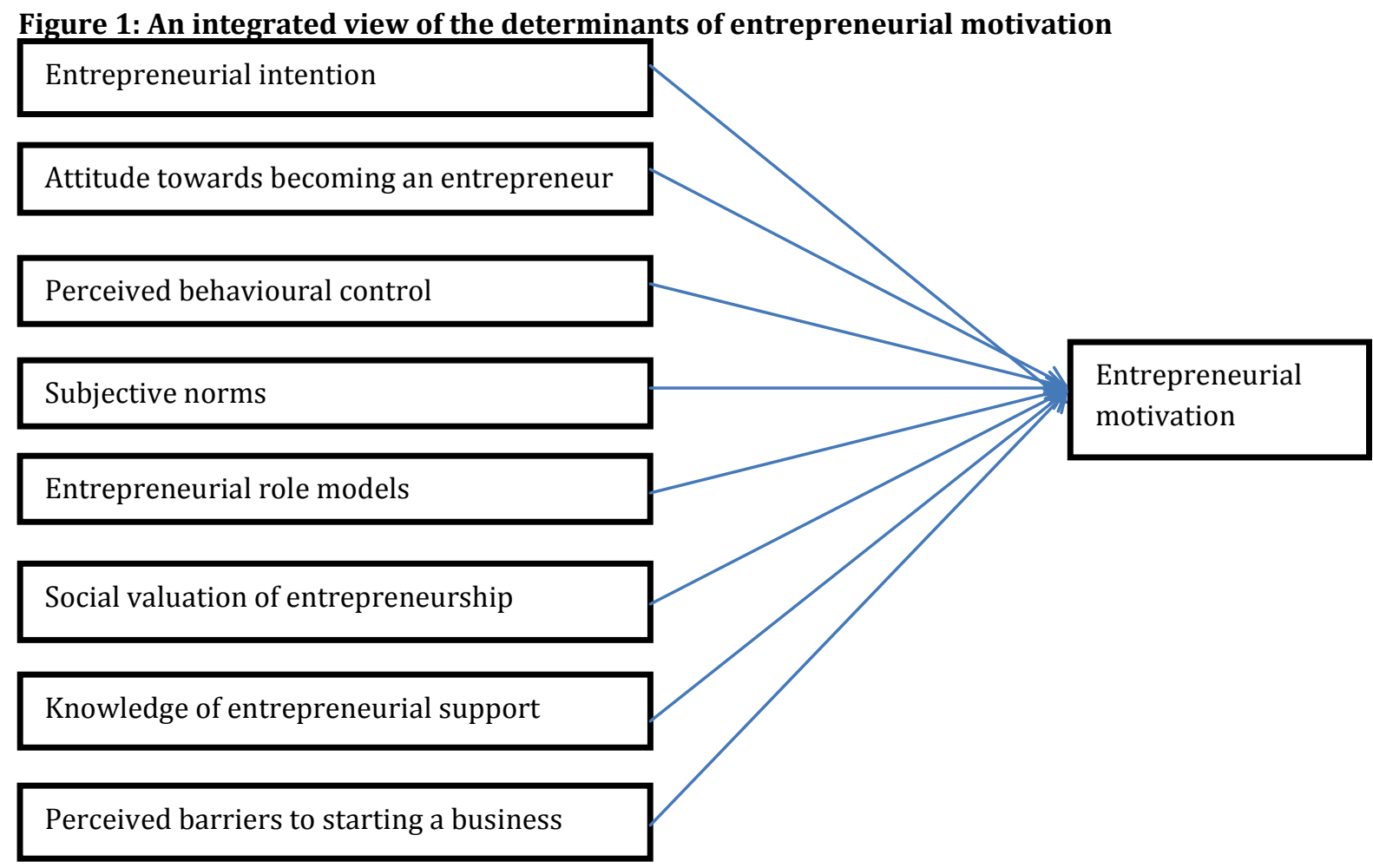

Theory of planned behaviour: The theory of planned behaviour has become the most influential and predominant framework in entrepreneurial intention research (Fayolle \& Liñán, 2014; Malebana, 2014a, 2014b; Schlaegel \& Koenig, 2014; Krueger et al., 2000).More recently it has been used to study the relationship between entrepreneurial motivation and entrepreneurial intention (Solesvik, 2013). The theory of planned behaviour suggests that the most important immediate determinant of action is a person's intention to perform or not to perform that action (Ajzen, 2012a, 2005). In this theory entrepreneurial intentions can be predicted with high accuracy from the attitude towards the behaviour, subjective norms and perceived behavioural control (Ajzen, 2005, 2014; Ajzen \& Sheikh, 2013). The 
attitude towards the behaviour represents a person's favourable or unfavourable evaluation of a particular behaviour. People develop attitudes from the beliefs they hold about the consequences of performing the behaviour (Ajzen, 2005). These attitudes may be favourable or unfavourable depending on individuals' experiences and observations of role models regarding the outcomes of performing the entrepreneurial behaviour. Ajzen and Sheikh (2013) are of the view that the performance of the behaviour can result in both positive and negative consequences. Direct experience with the entrepreneurial behaviour or observing relatives who are entrepreneurs can be a source of learning regarding the potential benefits or hardships of being an entrepreneur. The more positive an individual finds an entrepreneurial experience the stronger would be the attractiveness of an entrepreneurial career (Krueger, 1993). Exposure to actual or symbolic representations of the behaviour can lead to automatic activation of favourable or unfavourable attitudes (Ajzen, 2012b).

Observing positive or negative outcomes resulting from the performance of the behaviour by others may also influence perceptions concerning the attractiveness of entrepreneurship and entrepreneurial intention (Zhang, Duysters \& Cloodt, 2013; Solesvik, 2013; Marques, Ferreira, Gomes \& Rodrigues, 2012; Liñán \& Chen, 2009). Entrepreneurial outcomes such as autonomy, authority, economic opportunity and self-realisation, financial success, role, and recognition are positively related to the attitude towards becoming an entrepreneur and entrepreneurial intention (Vanevenhoven \& Liguori, 2013; Kolvereid \& Isaksen, 2006).These outcomes have been widely stated in entrepreneurial motivation research as reasons or motives for starting a business (Moore, Petty, Palich \& Longenecker, 2010; Carter, Gartner, Shaver \& Gatewood, 2003). Since entrepreneurial motivation serves as a link between entrepreneurial intention and action (Carsrud and Brännback, 2011), it is therefore the strength of the attractiveness of these entrepreneurial outcomes to intending entrepreneurs that would drive them to exert more effort to engage in entrepreneurship. Individuals who have realised positive outcomes from their own behaviour would be motivated to continue performing the same behaviour (Naffziger et al.,1994) while those who have observed others achieving positive outcomes from certain behaviours would be motivated to emulate the behaviours of such role models (Bandura, 1986). Social norms and values regarding entrepreneurship contribute to the formation of positive attitudes towards entrepreneurship. Individuals are more likely to hold positive attitudes towards entrepreneurship when their decision to engage in it is approved by significant others in their environments and when entrepreneurship is positively valued by those close to them (Liñán et al., 2013; Liñán et al., 2011; Katono et al., 2010; Guerrero, Lavín \& Álvarez, 2009; Liñán, 2008).These social norms and values can also strengthen the motivation to take action of starting a business.

Perceived behavioural control refers to individuals' assessments of the degree to which they are capable of performing a given behaviour. The intention to start a business is driven by individuals' perceptions of their capability to act entrepreneurially (Amorós \& Bosma, 2014). Townsend, Busenitz and Arthurs, (2010) reported that perceived ability exerts a greater effect on the motivation to start a business than perceived outcomes. This means that individuals must first believe that they have what it takes to succeed in performing the tasks associated with starting a business so that they can realise the expected outcomes. Individuals should have the skills to identify, evaluate and exploit opportunities in the market. Perceived behavioural control is determined by control beliefs concerning the availability of factors that can facilitate or impede performance of the behaviour (Ajzen, 2012a, 2011, 2005). The availability of market opportunities, resources, role models, social support from others and entrepreneurial support can enhance perceptions of control over the behaviour. Individuals who possess the necessary knowledge and skills to start a business and who know other people who are entrepreneurs are more likely to identify business opportunities (Geissler \& Zanger, 2013; Ramos-Rodríguez, Medina-Garrido, LorenzoGómez \& Ruiz-Navarro, 2010). Research findings have shown that opportunity recognition has a positive relationship with entrepreneurial intention (Zhang \& Yang, 2006) and nascent entrepreneurship (Arenius \& Minniti, 2005).

The motivation to start a business depends on identifying role models that one can emulate and who would become a source of inspiration and learning to other individuals. This is what Bandura (1986) refers to as vicarious motivators. Individuals' perceptions of environmental support increase when they have access to entrepreneurial role models (Gaglio \& Winter, 2009).Exposure to entrepreneurial role models can enhance perceptions of entrepreneurial self-efficacy or perceived behavioural control (Solesvik, 2013; Uygun \& Kasimoglu, 2012; Boyd \& Vozikis, 1994) and entrepreneurial motivation (Vanevenhoven \& Liguori, 2013; Rahman \& Day, 2013; Bandura, 2009) and increases the likelihood of becoming a nascent entrepreneur (Arenius \& Minniti, 2005). A similar concept to perceived behavioural 
control is entrepreneurial self-efficacy (Liñán et al., 2011; Krueger \& Brazeal, 1994). Entrepreneurial selfefficacy is a factor that has been strongly linked to motivation (Wang, Prieto \& Hinrichs, 2010; Bandura, 1986) and entrepreneurial intention (Saeed, Yousafzai, Yani-De-Soriano, \& Muffatto, 2013; Chen \& He, 2011; Vanevenhoven \& Liguori, 2013). Entrepreneurial self-efficacy can influence entrepreneurial motivation by impacting on the goals and aspirations of individuals and how they view opportunities and obstacles (Bandura, 2006).

Following the identification and evaluation of opportunities, entrepreneurs should be able to access the necessary resources to create new ventures (Spinelli \& Adams, 2012; Sriram, Mersha \& Herron, 2007; Shook et al., 2003). Even though individuals would have intentions to engage in a particular behaviour they often fail act on these intentions (Ajzen, 2011, 2005). This occurs because of perceived barriers that could prevent individuals from acting on their intentions (Ajzen, 2012b; Carsrud \& Brännback, 2011). Entrepreneurship literature highlights barriers impacting negatively on entrepreneurial activity. These barriers have been categorised as lack of support structure and fiscal or administrative costs, lack of knowledge and experience, economic climate and lack of entrepreneurial competencies, lack of selfconfidence and risk aversion (Giacomin et al., 2011). Choo and Wong (2006) suggested that these barriers include hard reality, lack of skills, compliance costs, lack of capital and lack of confidence. Social norms and interventions that include entrepreneurial support can positively affect entrepreneurial motivation and perceived skills and access to resources (Sriram et al., 2007). Entrepreneurial and social support and entrepreneurship education can play a vital role in assisting entrepreneurs to overcome these barriers (Smith \& Beasley, 2011). The government and other institutions that have the responsibility for entrepreneurship development can enhance perceived behavioural control by providing more information about their types of support and increasing their access. Research findings indicate that the knowledge of the entrepreneurial environment (awareness of associations, support bodies, training and support measures, and access to preferential loans) or entrepreneurial support has a positive effect on perceived behavioural control (Malebana, 2014a; Liñán et al., 2013).The availability of entrepreneurial support is positively related to transition to owning and operating a new venture (Zanakis, Renko \& Bullough, 2012) and entrepreneurial self-efficacy (Saeed et al., 2013) as well as new venture start-up (Delanoë, 2013). The provision of the requisite resources and the removal of potential barriers to the performance of the behaviour are crucial in facilitating the translation of entrepreneurial intention into the establishment of new ventures (Ajzen, 2014; Henley, 2005).

The belief that one's decision to engage in entrepreneurship will be approved by significant others (Liñán, 2008) and the value attached to entrepreneurial activity in the closer (Katono et al., 2010) and social environments have a positive impact on perceived behavioural control (Liñán et al., 2013; Liñán et al., 2011; Guerrero et al., 2009). Moreover, individuals' perceptions of their own entrepreneurial skills are more likely to be enhanced when entrepreneurial activity is positively valued in both the closer and social environments (Liñán et al., 2013; Liñán 2008). Entrepreneurial motivation is more likely to be enhanced by favourable attitudes of the society towards entrepreneurship and public support for entrepreneurial activities (Gnyawali \& Fogel, 1994). Given the high uncertainty and risks associated with entrepreneurial activities, individuals who perceive that the society values these activities are more likely to display their willingness exert efforts in performing them. These social valuations enhance the capability to engage in the search, discovery and ultimate exploitation of entrepreneurial opportunities.

Subjective norms refer to the perceived social pressure to perform or not to perform the behaviour. Social norms influence both perceived behavioural control and the attitude towards becoming an entrepreneur (Liñán et al., 2013; Byabashaija \& Katono, 2011; Liñán et al., 2011; Liñán \& Chen, 2009) as well as the intention to start a business (Schlaegel \& Koenig, 2014; Katono et al., 2010). The more individuals perceive that entrepreneurial behaviour is approved by those close to them the stronger will be their entrepreneurial intention, self-efficacy and motivation (Vanevenhoven \& Liguori, 2013). Social norms that support entrepreneurial behaviour enhance entrepreneurial motivation by generating positive entrepreneurial attitudes and strengthening perceived capability to start a business. Start-up motivation is more likely to be enhanced in an environment with strong socially supportive norms that reward individual accomplishment (Hopp \& Stephan, 2012). The more supportive the culture is of entrepreneurial activities, the higher will be the country's entrepreneurship rate (Stephan \& Uhlaner, 2010).

Entrepreneurial motivation theories: Various approaches have been used to explain entrepreneurial motivation. The quantitative approach identified motivational concepts such as the need for achievement, 
risk taking, tolerance for ambiguity, locus of control, self-efficacy and goal-setting. On the other hand, the qualitative approach suggested that entrepreneurial motivation can be understood from concepts that include independence, drive and egoistic passion (Rahman \& Day, 2013; Collins, Hanges \& Locke, 2004; Shane et al., 2003).Reasons, motives, or goals of entrepreneurs for starting a business (Moore et al., 2010; Carter et al., 2003; Shaver \& Scott, 1991), the utility maximisation theories(Douglas \& Fitzsimmons, 2006, Douglas \&shepherd, 2002) and the expectancy theory (Renko, Kroeck \& Bullough, 2012; Manolova, Brush \&Edelman, 2008; Gatewood, Shaver, Powers \& Gartner, 2002; Vesalainen \& Pihkala, 1999) have been used widely to explain entrepreneurial motivation. Researchers following the expectancy theory confirm that entrepreneurial outcomes play a significant role in the intention and motivation to start and grow a business, indicating support for the expectancy model as an approach to understanding entrepreneurial motivation (Renko et al., 2012; Edelman, Brush, Manolova \& Greene, 2010; Manolova et al., 2008). The more individuals think that they would be able to achieve these outcomes by starting or growing a business the stronger will be their motivation to start or intentions to grow the business.

Entrepreneurial motivation is considered to be very wide for one to explore all aspects in a single study (Solesvik, 2013). As a result, this study focuses on the reasons, motives or goals that motivate individuals to start their own businesses. Studies on the reasons, motives, or goals for starting a business deal with pull and push factors (Hessels, van Gelderen \& Thurik, 2008) or alternatively necessity and opportunity motives (Herrington \& Kelley, 2013; Herrington \& Kew, 2014). Individuals who are driven by pull factors become entrepreneurs because they perceive an entrepreneurial career option to be attractive whereas those who are pushed decide to pursue entrepreneurship because traditional jobs have become less attractive. Pull factors include the profit motive, challenge and desire for independence, personal development, achievement and recognition (Wickham, 2006). Push factors involve poor pay and lack of prospects, lack of innovation and negative displacement or lack of alternatives, unemployment and job insecurity. Prior studies report that entrepreneurs start their own businesses in order to enjoy the benefits offered by entrepreneurship (pull factors) and because of the push factors (García-Rodríguez, Gil-Soto, Ruiz-Rosa \& Sene, 2013; Krishna, 2013; Moore et al., 2010; Liang \& Dunn, 2007; Henley, 2005). In a study involving a representative sample of 1000 nascent entrepreneurs, Schjoedt and Shaver (2007) found that new ventures are started by individuals who leave their jobs despite being happy in those jobs. Therefore, both pull and push factors are valuable in understanding why individuals decide to start a business.

\section{Methodology}

Sample: A survey was conducted among a sample of 329 final year rural university students in the Limpopo Province in South Africa. The respondents were obtained using convenience and purposive sampling methods. This group of students was chosen because they were suitable for studying entrepreneurial intentions and the motives for starting a business as they are facing important career decisions on completion of their studies of which entrepreneurship could be one of them. This is in line with other similar studies such as (Solesvik, 2013; Liñán et al., 2011; Liñán \& Chen, 2009; Krueger et al., 2000). While this sample was easily obtained and consisted of people who had to make decisions regarding their future careers upon completion of their studies, it is not a representative sample of all final year students.

\section{Data collection}

Questionnaire design and measures: The instrument for data collection was designed based on structured and validated questionnaires that were used in previous studies on entrepreneurial motivation and barriers to starting a business (Choo \&Wong, 2006; Carter et al.,2003) and entrepreneurial intention (Liñán et al., 2011; Liñán \& Chen, 2009; Guerrero et al., 2009). Questions on entrepreneurial support were adopted from Malebana (2014a, 2012) while those on social valuation of entrepreneurship were adopted from Liñán (2008), Guerrero et al. (2009) and Liñán et al. (2011). Data on knowledge of entrepreneurial role models were collected by asking the respondents two questions on whether they personally know someone who is an entrepreneur and know successful entrepreneurs in their communities that were adopted from Liñán and Santos (2007) and Liao and Welsch (2005). The questionnaire consisted of questions that were based on the seven-point Likert scale (1=Strongly disagree and 7=Strongly agree) and nominal scales. Likert scale type questions were used for entrepreneurial intention (four items), attitude towards becoming an entrepreneur (five items), perceived behavioural control (seven items), subjective norms (three items), social valuation of 
entrepreneurship(five items), knowledge of entrepreneurial role models (two items)and entrepreneurial support (five items), perceived barriers to starting a business (21 items) and entrepreneurial motives (10 items). Demographic variables included gender $(0=$ Male and $1=$ Female $)$ and prior entrepreneurial exposure (whether the respondents currently own a business or have tried to start a business before or are from an entrepreneurial family background $(0=\mathrm{Yes}$ and $1=\mathrm{No})$ ) and they were entered as dummy variables.

Distribution of questionnaires: Questionnaires were distributed to the students during their lectures. Students were asked to complete the questionnaires in the presence of the researcher and return them immediately after completion. The respondents were informed about the purpose of the research and were asked to participate voluntarily in the study by completing questionnaires. They were also assured of complete anonymity. It took at least 10 minutes to complete the questionnaires.

\section{Data analysis}

Reliability of the questionnaire: This study was mainly concerned with the influence of entrepreneurial intention and its determinants, social valuation of entrepreneurship, entrepreneurial role models, entrepreneurial support and perceived barriers to starting a business on entrepreneurial motivation. For this reason the dependent variable was entrepreneurial motivation while the independent variables were entrepreneurial intention and its determinants, social valuation of entrepreneurship, knowledge of entrepreneurial role models and entrepreneurial support, and perceived barriers to starting a business. The internal consistency of the measuring instrument was tested by means of Cronbach's alpha. Cronbach's alpha scores were .750 for entrepreneurial intention, .766 for the attitude towards becoming an entrepreneur, .762 for perceived behavioural control, .784 for subjective norms, .694 for social valuation of entrepreneurship, 699 for entrepreneurial role models, .702 for entrepreneurial support, .918 for perceived barriers and .889 for entrepreneurial motivation (Table 1). Cronbach's alpha scores of the data collection instrument were higher than 0.60 as suggested by Garson (2009), meaning that it was a reliable tool for use in this research.

Convergent validity was determined by conducting factor analysis (Liñán \& Chen, 2009; Guerrero et al., 2009). Factors were extracted with the principal component analysis using the Varimax rotation method. Kaiser-Meyer-Olkin (KMO) measure of sampling adequacy for the independent variables ranged from .500 to .924 and was .898 for the dependent variable (Table 1). Bartlett's Test of Sphericity was highly significant $(\mathrm{p}<0.001)$.Principal component analysis extracted 15 factors with eigenvalues greater than 1 which accounted for $63.7 \%$ of variance explained. The results of the principal component analysis revealed one component for entrepreneurial intention that explained $57.4 \%$ of variance, one component for the attitude towards becoming an entrepreneur that explained $52.7 \%$ of variance, one component for perceived behavioural control that explained $41.6 \%$ of variance, one component for subjective norms that explained $60 \%$ of variance, one component for social valuation of entrepreneurship that explained $45 \%$ of variance, one component for entrepreneurial support that explained $45.7 \%$ of variance, one component for entrepreneurial role models that explained $76.9 \%$ of variance, one component for perceived barriers that explained $38.4 \%$ of variance, and one component for entrepreneurial motivation that explained $50.9 \%$ of variance. These results therefore supported the unidimensionality of the scales.

Discriminant analysis was conducted for the data by entering the independent variables together and the results were significant (Table 2). Box $M$ test results were significant (Box $M=117.859, F=3.179, p<$ $0.000)$. Wilk's Lambda for the independent variables and the dependent variable was also significant $\mathrm{p}<$ 0.001).These results suggest that the group means were significantly different. Furthermore, the results of the Kruskal-Wallis test showed that entrepreneurial motivation of the respondents was significantly different $(\mathrm{p}<0.000)$ for all the independent variables, thus providing support for the Box M test results and Wilk's Lambda. The results of the Standardised Canonical Discriminant function showed that entrepreneurial motivation was strongly predicted by entrepreneurial intention $(0.384)$, followed by social valuation of entrepreneurship (0.367), knowledge of entrepreneurial support (0.235), knowledge of entrepreneurial role models (0.224), perceived barriers to starting a business $(0.161)$, the attitude towards becoming an entrepreneur (0.131), and perceived behavioural control $(0.087)$. 


\begin{tabular}{|c|c|c|c|c|}
\hline \multirow[t]{2}{*}{ Descriptic } & & \multirow{2}{*}{$\begin{array}{l}\text { Factor } \\
\text { analysis }\end{array}$} & \multicolumn{2}{|c|}{ Reliability analysis } \\
\hline & & & \multirow{2}{*}{$\begin{array}{c}\text { Cronbach's } \\
\alpha\end{array}$} & \multirow{2}{*}{$\begin{array}{c}\begin{array}{c}\text { Item to } \\
\text { total }\end{array} \\
.541\end{array}$} \\
\hline \multirow{4}{*}{ 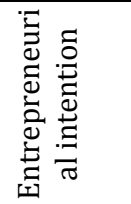 } & I am ready to do anything to be an entrepreneur & & & \\
\hline & My professional goal is to be an entrepreneur & & \multirow[b]{3}{*}{0.750} & .604 \\
\hline & I will make every effort to start and run my own business & KMO 0.764 & & .561 \\
\hline & I am determined to create a business venture in the future & $X^{2} 292.31$ & & .479 \\
\hline \multirow{5}{*}{ 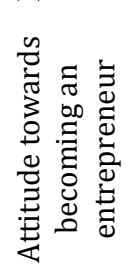 } & $\begin{array}{l}\text { Being an entrepreneur implies more advantages than } \\
\text { disadvantages to me }\end{array}$ & & \multirow{5}{*}{0.766} & .425 \\
\hline & A career as an entrepreneur is totally attractive to me & & & .567 \\
\hline & $\begin{array}{l}\text { If I had the opportunity and resources, I would like to start a } \\
\text { business }\end{array}$ & KMO 0.796 & & .684 \\
\hline & Amongst various options, I would rather be an entrepreneur & $\mathrm{X}^{2} 412.76$ & & .565 \\
\hline & Being an entrepreneur would give me great satisfaction & Sig. 0.000 & & .462 \\
\hline \multirow{7}{*}{ 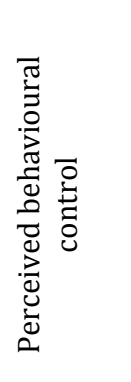 } & To start a business and keep it working would be easy for me & & \multirow{7}{*}{0.762} & .501 \\
\hline & I am able to control the creation process of a new business & & & .489 \\
\hline & $\begin{array}{l}\text { I would have complete control over the situation if I start and } \\
\text { run a business }\end{array}$ & & & .440 \\
\hline & I am prepared to do anything to be an entrepreneur & & & .460 \\
\hline & $\begin{array}{l}\text { I know all about the necessary practical details needed to start } \\
\text { a business }\end{array}$ & KMO 0.839 & & .538 \\
\hline & If I wanted to, I could easily start and run a business & $\mathrm{X}^{2} 438.00$ & & .555 \\
\hline & $\begin{array}{l}\text { If I tried to start a business, I would have a high chance of being } \\
\text { successful }\end{array}$ & Sig. 0.000 & & .393 \\
\hline \multirow{3}{*}{ 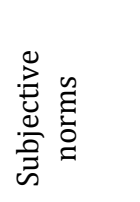 } & \multirow{3}{*}{$\begin{array}{l}\text { My friends would approve of the decision to start a business } \\
\text { My immediate family would approve of the decision to start a } \\
\text { business } \\
\text { My colleagues would approve of the decision to start a } \\
\text { business }\end{array}$} & & & .466 \\
\hline & & KMO 0.662 & & .483 \\
\hline & & $\begin{array}{l}\mathrm{X}^{2} 141.95 \\
\text { Sig. } 0.000\end{array}$ & 0.784 & .484 \\
\hline \multirow{5}{*}{ 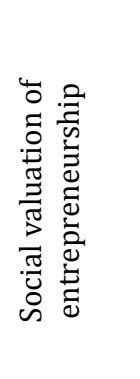 } & $\begin{array}{l}\text { My immediate family values entrepreneurial activity above } \\
\text { other activities and careers }\end{array}$ & & \multirow{5}{*}{0.694} & .468 \\
\hline & $\begin{array}{l}\text { My friends value entrepreneurial activity above other activities } \\
\text { and careers }\end{array}$ & & & .443 \\
\hline & $\begin{array}{l}\text { My colleagues value entrepreneurial activity above other } \\
\text { activities and careers }\end{array}$ & $\begin{array}{l}\text { KMO } 0.754 \\
X^{2} 240.26\end{array}$ & & .473 \\
\hline & $\begin{array}{l}\text { In my country, entrepreneurial activity is considered to be } \\
\text { worthwhile, despite the risks }\end{array}$ & Sig. 0.000 & & .458 \\
\hline & $\begin{array}{l}\text { The culture in my country is highly favourable towards the } \\
\text { entrepreneurial activity }\end{array}$ & & & .402 \\
\hline \multirow{2}{*}{$\begin{array}{l}\frac{n}{0} \\
\frac{0}{0} \\
\stackrel{\Xi}{0} \\
\frac{0}{0} \\
0\end{array}$} & \multirow{2}{*}{$\begin{array}{l}\text { I personally know other people who are entrepreneurs } \\
\text { I personally know successful entrepreneurs in my community }\end{array}$} & & & .537 \\
\hline & & $\begin{array}{l}\text { KMO } 0.500 \\
X^{2} 111.32 \\
\text { Sig. } 0.000\end{array}$ & 0.699 & .537 \\
\hline \multirow{5}{*}{ 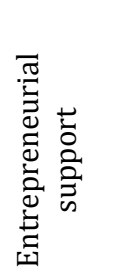 } & $\begin{array}{l}\text { I know the different types of support offered to people who } \\
\text { want to start new businesses }\end{array}$ & & \multirow{13}{*}{0.702} & .476 \\
\hline & Information about government support is accessible & & & .439 \\
\hline & $\begin{array}{l}\text { My level of knowledge about the types of support offered to } \\
\text { people who want to start a business is high }\end{array}$ & KMO 0.665 & & .462 \\
\hline & The government provides adequate support to start a business & $X^{2} 320.95$ & & .437 \\
\hline & The government provides quality support to start a business & Sig. 0.000 & & .478 \\
\hline \multirow{8}{*}{ 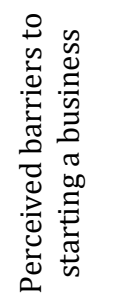 } & Lack of human resource management skills & & & .382 \\
\hline & Lack of operations skills & & & .389 \\
\hline & Lack of business planning skills & & & .476 \\
\hline & Lack of general management skills & & & .532 \\
\hline & Lack of financial skills & & & .420 \\
\hline & Lack of marketing skills & & & .642 \\
\hline & Lack of savings or assets & & & .604 \\
\hline & Lack of suitable premises & & & .633 \\
\hline
\end{tabular}


Difficulty in convincing others to support your idea

Difficulty in finding suitable labour

High taxes and fees

Compliance with government regulations

Fear of failure

Difficulty in obtaining finance

$\begin{array}{ll} & .648 \\ \text { KMO } 0.924 & .648\end{array}$

There is high risk in starting a new business

$\mathrm{X}^{2} 2934.72$

0.918

.575

Sig. $0.000 \quad .644$

The uncertainty of the future

Bad economic indicators in general

Lack of information about business start-ups

Lack of knowledge about where to obtain support

Lack of support from family/friends

Finding the right partner

To be my own boss

To challenge myself

To take advantage of my creative talents

To earn more money

To take advantage of a market opportunity

To maintain a family tradition

To increase my status/prestige

To follow the example of a person I admire

Sig. 0.000

Table 2: Tests of Equality of Group Means

\begin{tabular}{llllll}
\hline & Wilks' Lambda & F & df1 & df2 & Sig. \\
\hline Entrepreneurial intention & .863 & 25.851 & 2 & 326 & .000 \\
Attitude towards becoming an entrepreneur & .869 & 24.468 & 2 & 326 & .000 \\
Perceived behavioural control & .891 & 19.870 & 2 & 326 & .000 \\
Subjective norms & .917 & 14.663 & 2 & 326 & .000 \\
Social valuation of entrepreneurship & .867 & 24.922 & 2 & 326 & .000 \\
Knowledge of entrepreneurial support & .915 & 15.178 & 2 & 326 & .000 \\
Entrepreneurial role models & .888 & 20.550 & 2 & 326 & .000 \\
Perceived barriers to starting a business & .960 & 6.728 & 2 & 326 & .001 \\
\hline
\end{tabular}

Data were further analysed by means of the SPSS using descriptive statistics, Pearson correlation and hierarchical multiple regression analysis. Descriptive statistics were used for the frequencies of the sample. The association between the dependent variable and independent variables was tested using the Pearson correlation and hierarchical multiple regression analysis. Data were tested for the independence of errors and multicollinearity. The value of the Durbin-Watson statistic of 2.021 was well within the acceptable range from 1 to 3 as suggested by Field (2005). Therefore, the data did not violate the assumption of independence of errors. The tolerance values for the independent variables ranged from .494 to .792. Since the tolerance values for all the independent variables were larger than .10, this means that multicollinearity was not a problem. Variance inflation factors (VIF) for the independent variables were also highly satisfactory ranging from 1.263 to 2.025 . Before testing the association between the independent variables and the dependent variable, control variables were entered first followed by the second regression analysis that included control variables and independent variables. In the third regression analysis entrepreneurial intention, the attitude towards becoming an entrepreneur, perceived behavioural control and subjective norms were entered as independent variables to test their association with entrepreneurial motivation. The fourth regression analysis was conducted to determine the association between entrepreneurial intention and its determinants, social valuation of entrepreneurship, knowledge of entrepreneurial role models and entrepreneurial support, perceived barriers to starting a business and entrepreneurial motivation. The last regression analysis tested whether social valuation of entrepreneurship, knowledge of entrepreneurial role models and entrepreneurial support, and perceived barriers to starting a business are related to entrepreneurial motivation.

\section{Results and Discussion}

Descriptive statistics of the sample characteristics: This study involved 329 final year rural university students who were registered for various commerce degrees. Of the 329 respondents $58.1 \%$ were female and $41.9 \%$ were male. In terms of age $25.8 \%$ were in the age category between 18 and 21 years, $61.1 \%$ of 
the respondents were in the age category between 22 and 25 years, $7.6 \%$ were in the age category between 26 and 30 years, $2.7 \%$ were in the age category between 31 and 35 years, while $2.7 \%$ were above 36 years. These statistics mean that about $96 \%$ of the respondents were falling in the youth category. In terms of prior exposure to entrepreneurship, $7 \%$ of the respondents were currently running their own businesses, $32.8 \%$ of the respondents had tried to start a business before while $28.6 \%$ of the respondents were coming from the families with members who are running businesses.

Descriptive statistics and correlations among variables are shown in Table 3.Entrepreneurial motivation was significantly correlated with having an entrepreneurial family background $(\mathrm{p}<.05)$, prior start-up experience $(\mathrm{p}<.01)$, entrepreneurial intention and its three determinants $(\mathrm{p}<.01)$, social valuation of entrepreneurship $(\mathrm{p}<.01)$, having entrepreneurial role models $(\mathrm{p}<.01)$, knowledge of entrepreneurial support $(\mathrm{p}<.01)$ and perceived barriers to starting a business $(\mathrm{p}<.01)$. The findings suggest that entrepreneurial motivation can be enhanced by prior start-up experience, supportive social values, exposure to entrepreneurial role models, increasing awareness of entrepreneurial support and removing barriers that could prevent the creation of new ventures. The results concur with those of Rahman and Day (2013); Vanevenhoven and Liguori (2013); Saeed et al. (2013); Hopp and Stephan (2012) and Smith and Beasley (2011). Social valuation of entrepreneurship, having entrepreneurial role models and the knowledge of entrepreneurial support were all significantly correlated with entrepreneurial intention and its determinants $(\mathrm{p}<.01)$. Perceived barriers to starting a business were significantly correlated with the three determinants of entrepreneurial intention but not with entrepreneurial intention. Having an entrepreneurial family background and prior start-up experience had a statistically significant correlation with entrepreneurial intention $(\mathrm{p}<.01)$, the attitude towards becoming an entrepreneur $(p<.01)$, perceived behavioural control $(\mathrm{p}<.01)$ and the motivation to start a business $(\mathrm{p}<.05 ; \mathrm{p}<.01)$. As expected a statistically significant positive correlation $(\mathrm{p}<.01)$ was found between entrepreneurial intention, perceived behavioural control, the attitude towards becoming an entrepreneur, subjective norms and the motivation to start a business. The results provide support for prior research that reported the relationship between entrepreneurial motivation and entrepreneurial intention (Achchuthan \& Nimalathasan, 2013; Vesalainen \& Pihkala, 1999) and the determinants of entrepreneurial intention (Solesvik, 2013). A moderate to strong correlation $(\mathrm{p}<.01)$ was found between perceived behavioural control, the attitude towards becoming an entrepreneur, subjective norms and entrepreneurial intention. Thus supporting relationships postulated in the theory of planned behaviour (Ajzen, 2014, 2012a, 2005).

Entrepreneurial motives of the respondents: Top motivators (based on the mean scores in Table 4) for the respondents were the need to be independent (own boss) (5.69), the need for challenge (5.68), the need to take advantage of one's creative talents (5.64), followed by the need to earn more money (5.53), the need to have an interesting job (5.49), the need to follow a role model (5.41) and market opportunity (5.28). The findings suggest that the respondents were driven by both intrinsic and extrinsic rewards and the need for independence. The results indicate that respondents were pulled rather than pushed to start a business. The need to increase status/prestige, the need for a job and the need to maintain a family tradition ranked low among the motives for starting a business among the respondents.

Table 3: Descriptive statistics and correlations among variables

\begin{tabular}{|c|c|c|c|c|c|c|c|c|c|c|c|c|c|c|c|c|c|c|}
\hline & Mean & SD & 1 & 2 & 3 & 4 & 5 & 6 & 7 & 8 & 9 & 10 & 11 & 12 & 13 & 14 & 15 & 16 \\
\hline Gender & 1.56 & .515 & & & & & & & & & & & & & & & & \\
\hline Age & 1.94 & .852 & .033 & 1 & & & & & & & & & & & & & & \\
\hline $\begin{array}{l}\text { Entrepreneurship } \\
\text { module }\end{array}$ & 1.57 & .496 & 5.027 & .050 & 1 & & & & & & & & & & & & & \\
\hline $\begin{array}{l}\text { Current employmen } \\
\text { status }\end{array}$ & th 1.96 & .188 & 3.055 & $-204^{* *}$ & ${ }^{* *} .094$ & 1 & & & & & & & & & & & & \\
\hline $\begin{array}{l}\text { Currently runs } \\
\text { business }\end{array}$ & a 1.92 & .188 & 3.042 & -.105 & 5.092 & $.174^{* *}$ & & & & & & & & & & & & \\
\hline $\begin{array}{l}\text { Family members run a } \\
\text { business }\end{array}$ & a 1.71 & .461 & 1.083 & -.019 & $.218^{* *}$ & ${ }^{* *} .054$ & $.133^{*}$ & 1 & & & & & & & & & & \\
\hline $\begin{array}{l}\text { Tried to start a busines } \\
\text { before }\end{array}$ & s 1.65 & .495 & $5.133^{*}$ & ${ }^{*}-.134^{*}$ & $*^{*} .101$ & $.126^{*}$ & $.286^{* *}$ & ${ }^{*} .242^{* *}$ & & & & & & & & & & \\
\hline $\begin{array}{l}\text { Entrepreneurial } \\
\text { intention }\end{array}$ & 2.22 & .960 & -.022 & $2-.022$ & $-219^{* *}$ & ${ }^{* *}-.040$ & -.061 & $-174^{*}$ & -173 & ** 1 & & & & & & & & \\
\hline $\begin{array}{lr}\text { Attitude } & \text { towards } \\
\text { becoming } & \text { ar } \\
\text { entrepreneur } & \end{array}$ & $\begin{array}{l}\text { Is } 2.20 \\
\text { n }\end{array}$ & .952 & $2-.066$ & $6-.038$ & $-222^{* *}$ & ${ }^{* *}-.027$ & -.055 & $-178^{*}$ & * -173 & $3^{* *} \cdot 645^{* *}$ & & & & & & & & \\
\hline $\begin{array}{l}\text { Perceived behavioura } \\
\text { control }\end{array}$ & al 2.10 & .977 & 7 -.061 & $1-.063$ & $-191^{* *}$ & ${ }^{* *} .036$ & -.017 & $-154^{*}$ & $*^{* *}-201$ & ${ }^{* *} .572^{* *}$ & .546 & & & & & & & \\
\hline
\end{tabular}




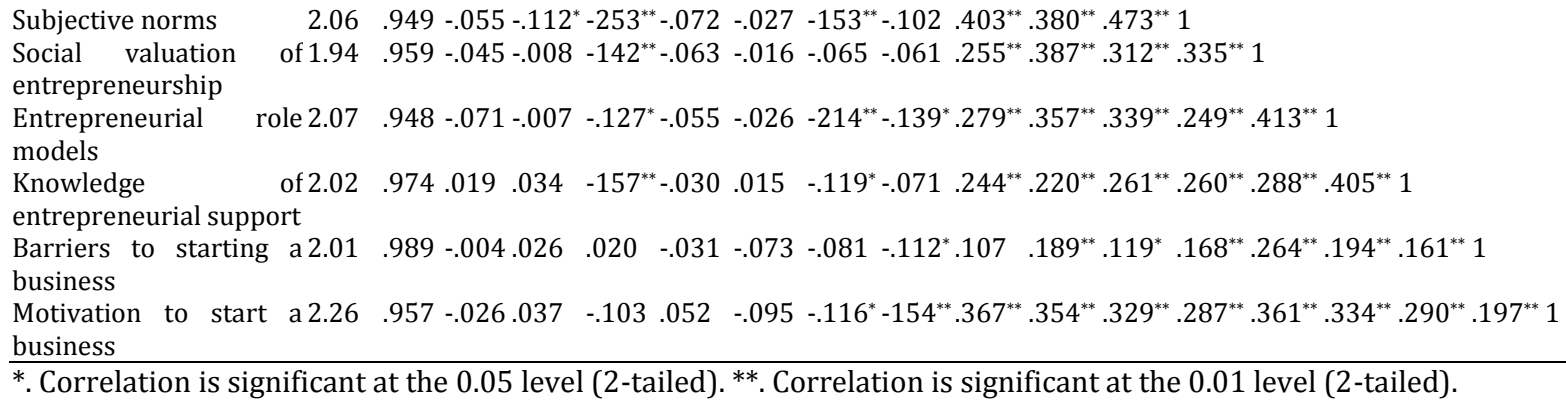

The relationship between entrepreneurial motivation and variables of the study: The results (Table 4) revealed that control variables had a very low effect on entrepreneurial motivation as they accounted for $4.6 \%$ of variance in entrepreneurial motivation $(F(7.321)=2.231 ; p<0.05)$. Of the control variables in Model 1 and Model 2, having tried to start a business before $(\beta=-0.119, p<0.05)$ and being currently employed $(\beta=0.115, p<0.05)$ were significantly related to entrepreneurial motivation. In line with previous research, the findings suggest that prior entrepreneurial experience and push factors influence the motivation to engage in entrepreneurship. Negative outcomes or hardships associated with entrepreneurship seem to have adverse effects on entrepreneurial motivation. On the other hand limitations of being an employee can impact positively on the motivation to start a business. The combination of control variables and all the independent variables (Model 2) accounted for a higher percentage of variance $(27.8 \%)$ in entrepreneurial motivation than all the models $(F(15.313)=8.019 ; p<$ 0.01). In Model 3 entrepreneurial intention $(\beta=0.170, p<0.05)$ and its determinants namely, the attitude towards becoming an entrepreneur $(\beta=0.148, \mathrm{p}<0.05)$ and subjective norms $(\beta=0.118, \mathrm{p}<0.05)$ were significantly related to the motivation to start a business, explaining $18 \%$ of variance in entrepreneurial motivation $(\mathrm{F}(4.324)=17.76 ; \mathrm{p}<0.01)$. The relationship between entrepreneurial motivation and entrepreneurial intention seems to support Carsrud \& Brännback's (2011) view that entrepreneurial motivation may be the link between entrepreneurial intention and action. This means that having formed the intention to start a business an individual's entrepreneurial motivation can be the spark that drives the entrepreneurial process forward. The role of entrepreneurial motivation as a link between intention and action is supported by the fact that individuals who have entrepreneurial intentions often fail to act on their intentions (Ajzen, 2005, 2011). Entrepreneurial motivation can increase the probability of action through the implementation intention which specifies where, when and how the behaviour will be performed. In this way the commitment to the action will be increased. Moreover, entrepreneurial motivation is significantly related to the attitude towards becoming an entrepreneur and subjective norms. As indicated in the literature, an individual will be motivated to engage in the entrepreneurial behaviour based on the attractiveness of the outcomes that can be achieved from it and the approval of significant others. The more attractive individuals find the outcomes that can be achieved by starting a business the stronger will be their motivation to start a business. The social pressure that individuals perceive to perform the behaviour and their motivation to comply with the expectations of significant others positively affect the motivation to start a business.

Table 4: Entrepreneurial motives of the respondents

\begin{tabular}{llll}
\hline & N & Mean & Std. Deviation \\
\hline To be my own boss & 329 & 5.69 & 1.949 \\
To challenge myself & 329 & 5.68 & 1.919 \\
To take advantage of my creative talents & 329 & 5.64 & 1.915 \\
To earn more money & 329 & 5.53 & 2.089 \\
To have an interesting job & 329 & 5.49 & 2.038 \\
To follow the example of a person I admire & 329 & 5.41 & 2.063 \\
To take advantage of a market opportunity & 329 & 5.28 & 2.058 \\
To increase my status/prestige & 329 & 5.16 & 2.142 \\
The need for a job & 329 & 4.82 & 2.263 \\
To maintain a family tradition & 329 & 4.74 & 2.356 \\
Valid N (listwise) & 329 & & \\
\hline
\end{tabular}

The results for Model 4 indicate that entrepreneurial intention and its determinants, social valuation of entrepreneurship, knowledge of entrepreneurial role models, knowledge of entrepreneurial support and perceived barriers to starting a business explained $25.7 \%$ of variance in entrepreneurial motivation ( $F$ $(8.320)=13.81 ; p<0.01)$. Social valuation of entrepreneurship, knowledge of entrepreneurial role 
models, knowledge of entrepreneurial support and perceived barriers to starting a business (Model 5) accounted for $19.6 \%$ of variance in entrepreneurial motivation ( $F(4.324)=19.75 ; \mathrm{p}<0.01)$. Taking into account the effect of all the independent variables from the five models, social valuation of entrepreneurship had the highest effect on entrepreneurial motivation $(\beta=0.230, p<0.01)$, followed by entrepreneurial intention $(\beta=0.178, p<0.01)$, knowledge of entrepreneurial role models $(\beta=0.165, p<$ $0.01)$, the attitude towards becoming an entrepreneur $(\beta=0.148, p<0.05)$, knowledge of entrepreneurial support $(\beta=0.144, p<0.01)$, and subjective norms $(\beta=0.118, p<0.05)$. Perceived behavioural control and perceived barriers to starting a business were not significant in explaining entrepreneurial motivation. The findings with regard to perceived behavioural control suggest that entrepreneurial motivation is not dependent on an individual's perceived capability. Instead high entrepreneurial motivation and perceived behavioural control can jointly increase the likelihood of performing the behaviour (Ajzen, 2005).

The findings with regard to social valuation of entrepreneurship and entrepreneurial role models support the view that entrepreneurial activity is a social activity. They suggest that the motivation to start a business is dependent on socially supportive values in both the closer and social environment of an individual and having entrepreneurial role models. Socially supportive values can positively enhance entrepreneurial motivation by appreciating the role of entrepreneurs and their successful efforts. In this way these values could be perceived as a form of social support that increases the likelihood of translating entrepreneurial intention into action (Carsrud \& Brännback, 2011; Ajzen, 2012a). Rahman and Day (2013) found that entrepreneurial role models have a positive effect on entrepreneurial motivation. These role models have a positive effect on becoming a nascent entrepreneur (Arenius \& Minniti, 2005). While socially supportive values and the presence of entrepreneurial role models have been found to influence entrepreneurial intention and its determinants they seem to affect entrepreneurial motivation by increasing the commitment to perform the intended behaviour. Therefore, efforts to stimulate entrepreneurial activity could benefit from positive social values regarding entrepreneurship and entrepreneurial role models who could be a source of learning for intending entrepreneurs.

Entrepreneurial motivation is also related to the knowledge of available entrepreneurial support programmes. This knowledge increases the probability of action by impacting positively on perceptions regarding the availability of required resources and other forms of assistance to perform the behaviour. This is not surprising given the fact that following the formation of entrepreneurial intention an individual would require resources to translate it into action (Ajzen, 2011, 2005; Shook et al., 2003). It has been found that perceived availability of entrepreneurial support and access to it can lead to the emergence of new ventures (Delanoë, 2013; Zanakis et al., 2012; Stephan \& Uhlaner, 2010) and positively influences start-up motivation (Hopp \& Stephan, 2012; Gnyawali \& Fogel, 1994). Thus increased perceptions concerning the availability of entrepreneurial support would lessen the effect of perceived barriers to starting a business on entrepreneurial motivation. Therefore, the provision of entrepreneurial support and increasing awareness of and access to it is vital in reducing potential barriers to the performance of the intended behaviour (Ajzen, 2014). Hence its positive effect on entrepreneurial motivation.

Table 5: Hierarchical regression models for the relationship between entrepreneurial motivation and the variables of the study

\begin{tabular}{|c|c|c|c|c|c|}
\hline & Model 1 & Model 2 & Model 3 & Model 4 & Model 5 \\
\hline & $\beta$ & $\beta$ & $\beta$ & $\beta$ & $\beta$ \\
\hline \multicolumn{6}{|l|}{ Control variables } \\
\hline Gender & -0.007 & 0.001 & & & \\
\hline Age & -0.037 & 0.058 & & & \\
\hline Entrepreneurship module & -0.082 & 0.023 & & & \\
\hline Current employment status & 0.096 & $0.115^{*}$ & & & \\
\hline Currently runs a business & -0.058 & -0.074 & & & \\
\hline Has tried to start a business before & $-0.119 *$ & -0.049 & & & \\
\hline Family members run a business & -0.065 & -0.004 & & & \\
\hline \multicolumn{6}{|l|}{ Independent variable } \\
\hline Entrepreneurial intention & & $0.177^{*}$ & $0.170^{*}$ & $0.178^{* *}$ & \\
\hline
\end{tabular}




\begin{tabular}{|c|c|c|c|c|c|}
\hline & 0.052 & $0.148^{*}$ & 0.053 & \\
\hline \multicolumn{2}{|l|}{$\begin{array}{l}\text { Attitude towards becoming an entrepreneur } \\
\text { Perceived behavioural control }\end{array}$} & 0.031 & 0.095 & 0.049 & \\
\hline \multicolumn{2}{|l|}{ Subjective norms } & 0.071 & $0.118^{*}$ & 0.049 & \\
\hline \multicolumn{2}{|l|}{ Social valuation of entrepreneurship } & $0.177^{* *}$ & & $0.169^{* *}$ & $0.230^{* *}$ \\
\hline \multicolumn{2}{|l|}{ Entrepreneurial role models } & 0.112 & & 0.111 & $0.165^{* *}$ \\
\hline \multicolumn{2}{|l|}{ Knowledge of entrepreneurial support } & 0.106 & & 0.105 & $0.144^{* *}$ \\
\hline \multicolumn{2}{|l|}{ Perceived barriers to starting a business } & 0.058 & & 0.071 & 0.081 \\
\hline Multiple $R$ & 0.215 & 0.527 & 0.424 & 0.507 & 0.443 \\
\hline R Square $\left(\mathrm{R}^{2}\right)$ & 0.046 & 0.278 & 0.180 & 0.257 & 0.196 \\
\hline$\Delta$ Adjusted $R^{2}$ & 0.026 & 0.243 & 0.170 & 0.238 & 0.186 \\
\hline$\Delta$ F-Ratio & 2.231 & 8.019 & 17.758 & 13.809 & 19.751 \\
\hline Significance of $F$ & $0.032 *$ & $0.000^{* *}$ & $0.000^{* *}$ & $0.000^{* *}$ & $0.000^{* *}$ \\
\hline
\end{tabular}

${ }^{*} \mathrm{P}<.05 * * \mathrm{P}<.01$

\section{Conclusion}

The purpose of this study was to identify the motives for starting a business among South African rural university students and to determine whether entrepreneurial motivation is significantly related to entrepreneurial intention and its determinants, social valuation of entrepreneurship, knowledge of entrepreneurial role models, knowledge of available entrepreneurial support and perceived barriers to starting a business. Top motivators for starting a business among the respondents were the need to be independent (own boss), the need for challenge, the need to take advantage of one's creative talents, followed by the need to earn more money, the need to have an interesting job, the need to follow a role model and market opportunity. This means that the respondents were rather more pulled into entrepreneurship than pushed into it. They wanted to be independent and achieve both intrinsic and extrinsic rewards. The findings support the results in the South African Global Entrepreneurship Monitor (SA GEM)and Sub-Saharan African Regional reports that have consistently shown that despite the high unemployment rates in the country, the decision to engage in entrepreneurial activity is driven more by opportunity motivation rather than necessity motivation (Herrington \& Kew, 2014; Herrington \& Kelley, 2013).

Statistically significant correlations were found between entrepreneurial motivation, having an entrepreneurial family background, prior start-up experience, entrepreneurial intention and its three determinants, social valuation of entrepreneurship, having entrepreneurial role models, knowledge of entrepreneurial support and perceived barriers to starting a business. The findings provide support for previous research that has emphasised the importance of prior exposure to entrepreneurship (for example Krueger, 1993; Rahman \& Day, 2013; Vanevenhoven \& Liguori, 2013), social valuation of entrepreneurship and social legitimisation of entrepreneurship (Kibler et al., 2014; Liñán et al., 2013; Liñán et al., 2011; Katono et al., 2010; Liñán, 2008), and perceptions regarding entrepreneurial and social support (Hopp \& Stephan, 2012; Zanakis et al., 2012; Stephan \&Uhlaner, 2010). They suggest that actions aimed at encouraging the formation of entrepreneurial intention, increasing exposure to entrepreneurial role models, positive social values regarding entrepreneurship and intensified efforts to promote the knowledge of entrepreneurial support programmes are vital to stimulate entrepreneurial motivation.

The findings suggest that the TPB is a valuable model for understanding the relationship between entrepreneurial motivation, entrepreneurial intention and the determinants of entrepreneurial intention. The results concur with those of Achchuthan and Nimalathasan (2013) in terms of the relationship between entrepreneurial motivation and entrepreneurial intention and Solesvik (2013) who reported that entrepreneurial motivation is positively related to the attitude towards becoming an entrepreneur, perceived behavioural control, subjective norms and entrepreneurial intention. However, the relationship between perceived behavioural control and entrepreneurial motivation in this study was only found in the correlation analysis (Table 3) and not in the regression analysis (Table 5). Compared to Solesvik (2013), this study followed Carsrud and Brännback's (2011) view that entrepreneurial motivation is a link between intention and action. The results indicate that entrepreneurial motivation can be predicted from the attitude towards becoming an entrepreneur, subjective norms and entrepreneurial intention. This means that individuals are more likely to be motivated to engage in entrepreneurship when they think doing so would lead to the attainment of desirable outcomes, doing so would receive approval of 
significant others and when they have strong intentions to do so. On the other hand the findings revealed that social valuation of entrepreneurship, having entrepreneurial role models and the knowledge of available entrepreneurial support have a significant relationship with entrepreneurial motivation. These findings confirm the view that entrepreneurial activity is shaped by the social environment in which entrepreneurs belong. As it has been noted in Herrington and Kew's (2014) findings, it seems that social and cultural norms are vital in enhancing positive perceptions concerning entrepreneurship as a viable career in South Africa.

The results have shed light into understanding entrepreneurial motivation of the youth in South Africa, since the majority of the respondents were the youth. This study has advanced the recent entrepreneurial motivation research that seeks to establish the link between entrepreneurial intention and motivation and the role of entrepreneurial motivation as a link between intention and action (for example Fayolle et al., 2014; Solesvik, 2013; Achchuthan \& Nimalathasan, 2013; Carsrud\& Brännback, 2011).This type of research is lacking in developing countries such as South Africa (Liñán et al., 2013; Nabi \& Liñán, 2011).This study has taken a novel approach to understanding entrepreneurial motivation by applying the TPB to examine the influence of entrepreneurial intention and its determinants, social valuation of entrepreneurship, entrepreneurial role models and the knowledge of available entrepreneurial support on entrepreneurial motivation. The findings have shown that entrepreneurial intention, the attitude towards becoming an entrepreneur and subjective norms have a positive effect on entrepreneurial motivation. In response Carsrud and Brännback's (2011) call, the role of the context in terms of its impact on entrepreneurial motivation has been uncovered. The presence of entrepreneurial role models, positive social values regarding entrepreneurial activity and the knowledge of available entrepreneurial support have a positive effect on entrepreneurial motivation.

Implications: The importance of this study lies in consistently low TEA rates that have been reported in the annual SA GEM reports since 2002 (Herrington \& Kew, 2014; Herrington \& Kelley, 2013). Since entrepreneurial motivation has been reported to be a link between intention and action (Carsrud \& Brännback, 2011), knowledge of the motives that influence individuals to start a business is vital in South Africa in order to develop targeted interventions aimed at encouraging people to start new ventures. The findings have implications for policymakers, the society and entrepreneurship education. The South African government and its institutions that have been mandated to provide support for entrepreneurship development should increase awareness of and access to entrepreneurial support to help improve South Africa' s TEA rates. This is in line with Stephan and Uhlaner's (2010) findings regarding the positive relationship between a socially supportive culture and the national entrepreneurship rate. In a socially supportive culture entrepreneurs are able to receive more help and support to create and run new ventures. Nascent entrepreneurs' perceptions regarding the support provided to new businesses by established institutions influences transition to owning and operating a business (Zanakis et al., 2012). The more entrepreneurs are able to access and know about entrepreneurial support the higher will be the probability of establishing new ventures (Delanoë, 2013). This will also impact positively on entrepreneurial self-efficacy (Saeed et al., 2013) and perceived behavioural control and indicate that entrepreneurial activity is socially valued (Linan et al., 2013). Increasing awareness of and access to entrepreneurial support will help alleviate perceptions regarding the impediments to the implementation of entrepreneurial intentions. Government institutions can help potential entrepreneurs to implement their intentions by providing information on market opportunities and facilitating the formation of social networks in which members could share information relating new opportunities. In this way potential entrepreneurs would discover opportunities that they can exploit to start a business (Arenius \& Minniti, 2005).According to Krueger and Brazeal (1994) visible support to both potential and existing entrepreneurs will enhance perceptions that entrepreneurial activity is desirable and feasible, thus increasing the motivation to act on entrepreneurial intentions.

Entrepreneurship educators can enhance entrepreneurial intention, the determinants of entrepreneurial intention and entrepreneurial motivation by emphasising the benefits of entrepreneurship and using entrepreneurs as guest speakers and case studies portraying the benefits of entrepreneurship. They can also contribute to entrepreneurship development by equipping students with the necessary skills and providing more targeted and specific support for creating a new venture (Saeed et al., 2013).With the confidence of being equipped with the right skills and constant interaction with entrepreneurs, the likelihood of starting new businesses will be enhanced among students with high levels of entrepreneurial motivation (Arenius \& Minniti, 2005). The society can positively influence entrepreneurial motivation by celebrating and recognising the role played by entrepreneurs. The more 
entrepreneurship is valued by the society in general as a viable career option the higher will be the motivation to engage in entrepreneurship. The study did not test the relationship between entrepreneurial motivation and the actual act of starting a business. Future studies in this direction would contribute towards a better understanding of how entrepreneurial motivation influences entrepreneurial behaviour. Although the results have shed light with regard to entrepreneurial motivation of final year rural university students, they may not be generalised to all final year students in South Africa owing to the use of convenience sampling.

Acknowledgements: This study was partially funded by the National Research Foundation. The researcher would like to thank Professor Francisco Liñán for the permission to use the Entrepreneurial Intention Questionnaire.

\section{References}

Achchuthan, S. \& Nimalathasan, B. (2013). Relationship between entrepreneurial motivation and entrepreneurial intention: A case study of management undergraduates of the University of Jaffna, Sri Lanka. Available at: http://www.academia.edu/2951985 /RELATIONSHIP_BETWEEN_ENTREPRENEURIAL_MOTIVATION_AND_ENTREPRENEURIAL_INT ENTION_A_CASE_STUDY_OF_MANAGEMENT_UNDERGRADUATES_OF_THE_UNIVERSITY_OF_JAFF NA_SRI_LANKA (accessed 18 August 2013).

Ajzen, I. (2005). Attitudes, personality and behaviour (2nd ed.), Berkshire, England: Open University Press.

Ajzen, I. (2011). Behavioural interventions: Design and evaluation guided by the theory of planned behaviour. In M.M. Mark., S.I. Donaldson, \& B.C. Campbell (Eds.).Social psychology for program and policy evaluation (pp. 74-100), New York: Guilford.

Ajzen, I. (2012a).The theory of planned behaviour. In Lange, P.A.M., Kruglanski, A.W.\& Higgins, E.T. (Eds).Handbook of theories of social psychology, Vol. 1, pp 438-459, London, UK: Sage.

Ajzen, I. (2012b). Attitudes and persuasion. In Deaux, K. \& Snyder, M. (Eds.), The Oxford handbook of personality and social psychology (pp. 367-393). New York: Oxford University Press.

Ajzen, I. (2014). The theory of planned behaviour is alive and well, and not ready to retire: a commentary on Sniehotta, Presseau, and Araujo-Soares. Health Psychology Review. Available at: http://dx.doi.org/10.1080/17437199.2014.883474 (accessed 13 April 2014).

Ajzen, I. \& Sheikh, S. (2013). Action versus inaction: anticipated affect in the theory of planned behaviour. Journal of Applied Social Psychology, 43, 155-162.

Amorós, J. E. \& Bosma, N. (2014). Global Entrepreneurship Monitor-2013 Global Report. Available at: http://www.gemconsortium.org/docs/download/3106 (accessed 30 April 2014).

Ardichvili, A., Cardozo, R. \& Ray, S. (2003). A theory of entrepreneurial opportunity identification and development. Journal of Business Venturing, 18, 105-123.

Arenius, P. \& Minniti, M. (2005).Perceptual variables and nascent entrepreneurship. Small Business Economics, 24, 233-247.

Bandura, A. (1986). Social foundation of thought and action-A social cognitive theory. Englewood Cliffs. New Jersey: Prentice-Hall.

Bandura, A. (2006). Toward a psychology of human agency. Perspectives on Psychological Science, 1(2), 164-180.

Bandura, A. (2009). Cultivate self-efficacy for personal and organizational effectiveness. In Locke, E.A. (Ed), Handbook of principles of organization behaviour (2nded.), (pp. 179-200). New York: Wiley.

Bird, B. (1988).Implementing entrepreneurial ideas: The case for intention. Academy of Management Review, 13(3), 442-453.

Boyd, N. G. \& Vozikis, G. S. (1994).The influence of self-efficacy on the development of entrepreneurial intentions and actions. Entrepreneurship Theory \& Practice, Summer, 63-74.

Byabashaija, W. \& Katono, I. (2011).The impact of college entrepreneurial education on entrepreneurial attitudes and intention to start a business in Uganda. Journal of Developmental Entrepreneurship, $16(1), 127-144$.

Carsrud, A. \& Brännback, M. (2011). Entrepreneurial motivations: What do we still need to know? Journal of Small Business Management, 49(1), 9-26.

Carter, N. M., Gartner, W. B., Shaver, K. G. \& Gatewood, E. J. (2003). Career reasons of nascent entrepreneurs. Journal of Business Venturing, 18, 13-39.

Chen, Y. \& He, Y. (2011). The impact of strong ties on entrepreneurial intention: An empirical study based on the mediating role of self-efficacy. Journal of Chinese Entrepreneurship, 3(2), 147-158. 
Choo, S. \& Wong, M. (2006). Entrepreneurial intention: Triggers and barriers to new venture creations in Singapore. Singapore management review, 28(2), 47-64.

Collins, C. J., Hanges, P. J. \& Locke, E. A. (2004). The relationship of achievement motivation to entrepreneurial behaviour: A meta-analysis. Human Performance, 17(1), 95-117.

Delmar, F. \& Wiklund, J. (2008). The effect of small business managers' growth motivation on firm growth: A longitudinal study. Entrepreneurship Theory \& Practice, 5, 437-457.

Delanoë, S. (2013). From intention to start-up: the effect of professional support. Journal of Small Business \& Enterprise Development, 20(2), 383-398.

Douglas, E. J. (2013). Reconstructing entrepreneurial intentions to identify predisposition for growth. Journal of Business Venturing, 28, 633-651.

Douglas, E. \& Fitzsimmons, J. (2006). Entrepreneurial capital and entrepreneurial intentions: A cross-cultural comparison. Paper presented at the 2005Babson Conference. Available at: http://www.babson.edu.entrep/fer/2005FER/chapter_v/summary_v2.html (accessed 09 Aug 2007).

Douglas, E. J. \& Shepherd, D. A. (2002). Self-employment as a career choice: Attitudes, entrepreneurial intentions, and utility maximization. Entrepreneurship Theory \& Practice, 3, 81-90.

Edelman, L. F., Brush, C. G., Manolova, T. S. \& Greene, P. G. (2010). Start-up motivations and growth intentions of minority nascent entrepreneurs. Journal of Small Business Management, 48(2), 174-196.

Estay, C., Durrieu, F. \& Akhter, M. (2013). Entrepreneurship: From motivation to start-up. Journal of International Entrepreneurship, 11, 243-267.

Fayolle, A. \& Liñán, F. (2014).The future of research on entrepreneurial intentions. Journal of Business Research, 67, 663-666.

Fayolle, A., Liñán, F. \& Moriano, J. A. (2014). Beyond entrepreneurial intentions: values and motivations in entrepreneurship. International Entrepreneurship \& Management Journal, DOI 10. 1007/s/11365-014-0306-7.

Field, A. (2005). Discovering statistics using SPSS. (2nd ed.), London: Sage publications.

Gaglio, C. M. \& Winter, S. (2009). Entrepreneurial alertness and opportunity identification: Where are we now? In Carsrud, A.L. \& Brännback, M. (eds.), Understanding the entrepreneurial mind, International Studies in Entrepreneurship, 24, 305-325, DOI 10.1007/978-1-4419-0443-0_14.

García-Rodríguez, F. J., Gil-Soto, E., Ruiz-Rosa, I. \& Sene, P. M. (2013). Entrepreneurial intentions in diverse development contexts: A cross-cultural comparison between Senegal and Spain. International Entrepreneurship \& Management Journal, DOI 10.1007/s11365-013-0291-2.

Garson, D. (2009). Reliability analysis. Available at: http://faculty.chass.ncsu.edu/garson/PA765/reliab.htm(accessed 20 March 2009).

Gatewood, E. J., Shaver, K. G., Powers, J. B. \& Gartner, W. B. (2002). Entrepreneurial expectancy, task effort, and performance. Entrepreneurship Theory \&Practice, winter, 187-203.

Geissler, M. \& Zanger, C. (2013). Entrepreneurial role models and their impact on the entrepreneurial prefounding process. Available at: http://sbaer.uca.edu/research/ICSB/2013/58.pdf (accessed 10 May 2014).

Giacomin, O., Janssen, F., Pruett, M., Shinnar, R. S., Llopis, F. \& Toney, B. (2011). Entrepreneurial intentions, motivations and barriers: Differences among American, Asian and European students. International Entrepreneurship \& Management Journal, 7, 219-238.

Gnyawali, D. R. \& Fogel, D. S. (1994). Environments for entrepreneurship development: Key dimensions and research implications. Entrepreneurship Theory \& Practice, Summer, 43-62.

Guerrero, M., Lavín, J. \& Álvarez, M. (2009).The role of education on start-up intentions: A structural equation model of Mexican university students. Paper presented at the $35^{\text {th }}$ annual conference proceedings of the Association for Small Business and Entrepreneurship.

Henley, A. (2005). From entrepreneurial aspiration to business start-up: Evidence from British longitudinal data. Available at: http://www.swan.ac.uk/sbe /research/working\%20papers/SBE\%202005\%202.pdf (accessed 01 November 2007).

Herrington, M. \& Kelley, D. (2013). African entrepreneurship - Sub-Saharan African Regional Report 2012. Available at: http://gemconsortium.org/docs/download/2909 (accessed 21 March 2014).

Herrington, M. \& Kew, J. (2014). GEM South Africa 2013 Report. Available at: http://www.gemconsortium.org /docs/3336/gem-south-africa-2013-report (accessed 30 April 2014).

Hessels, J., van Gelderen, M. \& Thurik, R. (2008). Drivers of entrepreneurial aspirations at the country level: The start-up motivations and social security. International Entrepreneurship \& Management Journal, 4, 401-417.

Hopp, C. \& Stephan, U. (2012). The influence of socio-cultural environments on the performance of nascent entrepreneurs: Community culture, motivation, self-efficacy and start-up success. Entrepreneurship \& Regional Development: An International Journal, 24(9-10), 917-945. 
Katono, I. W., Heintze, A. \& Byabashaija, W. (2010). Environmental factors and graduate start up in Uganda. Paper presented at the Conference on Entrepreneurship in Africa. New York: Whitman School of Management, Syracuse University.

Kibler, E., Kautonen, T. \& Fink, M. (2014). Regional social legitimacy of entrepreneurship: Implications for entrepreneurial intention and start-up behaviour. Regional Studies, DOI: 10.1080/00343404.2013.851373.

Kolvereid, L. \& Isaksen, E. (2006).New business start-up and subsequent entry into self-employment. Journal of Business Venturing, 21, 866-885.

Krishna, M. (2013). Entrepreneurial motivation: A case study of small scale entrepreneurs in Mekelle, Ethopia. Journal of Business Management \& Social Sciences Research, 2(1), 1-6.

Krueger, N. (1993). The impact of prior entrepreneurial exposure on perceptions of new venture feasibility and desirability. Entrepreneurship Theory \& Practice, Fall, 5-21.

Krueger, N. F. \& Brazeal, D. V. (1994). Entrepreneurial potential and potential entrepreneurs. Entrepreneurship Theory \& Practice, Spring, 91-104.

Krueger, N., Liñán, F. \& Nabi, G. (2013).Cultural values and entrepreneurship. Entrepreneurship \& Regional Development: An International Journal, 25(9-10), 703-707.

Krueger, N. F., Reilly, M. D. \& Carsrud, A. L. (2000).Competing models of entrepreneurial intentions. Journal of Business Venturing, 15, 411-432.

Kuratko, D. F. \& Hodgetts, R. M. (2007). Entrepreneurship-Theory, process and practice (7thed.), Canada: Thomson, South-Western.

Liang, C. \& Dunn, P. (2007). Triggers of the decision to launch a new venture - Is there any difference between pre-business and in-business entrepreneurs? Academy of Entrepreneurship Journal, 13(1), 79-88.

Liao, J. \& Welsch, H. (2005). Roles of social capital in venture creation: Key dimensions and research implications. Journal of Small Business Management, 43(4), 345-362.

Liñán, F. (2008). Skill and value perceptions: how do they affect entrepreneurial intentions? International Entrepreneurship \& Management Journal, 4, 257-272.

Liñán, F. \& Chen, Y. (2009). Development and cross-cultural application of a specific instrument to measure entrepreneurial intentions. Entrepreneurship Theory \& Practice, May, 593-617.

Liñán, F., Nabi, G. \& Krueger, N. (2013). British and Spanish entrepreneurial intentions: A comparative study. Revista De Economia Mundial, 33, 73-103.

Liñán, F. \& Santos, F.J. (2007). Does social capital affect entrepreneurial intentions? International Advances in Economic Research, 13, 443-453.

Liñán, F., Urbano, D. \& Guerrero, M. (2011).Regional variations in entrepreneurial cognitions: Start-up intentions of university students in Spain. Entrepreneurship \& Regional Development, 23(3), 187-215.

Locke, E. A. \& Latham, G. P. (2004). What should we do about motivation theory? Six recommendations for the twenty-first century. Academy of Management Review, 29(3), 388-403.

Malebana, M.J. (2012). Entrepreneurial intent of final-year commerce students in the rural provinces of South Africa. Unpublished doctoral thesis. Pretoria: University of South Africa.

Malebana, M. J. (2014a). The effect of knowledge of entrepreneurial support on entrepreneurial intention. Mediterranean Journal of Social Sciences, 5(17), In press.

Malebana, J. (2014b). Entrepreneurial intentions of South African rural university students: A test of the theory of planned behaviour. Journal of Economics \& Behavioral Studies, 6(2), 130-143.

Manolova, T. S., Brush, C. G. \& Edelman, L. F. (2008). What do women entrepreneurs want? Strategic Change, 17, 69-82.

Marques, C. S., Ferreira, J. J., Gomes, D. N. \& Rodriques, R. G. (2012). Entrepreneurship education: How psychological, demographic and behavioural factors predict the entrepreneurial intention. Education \& Training, 54 (8/9), 657-672.

Moore, C. W., Petty, J. W., Palich, L. E. \& Longenecker, J. G. (2010). Managing small business-An entrepreneurial emphasis. International edition, China: Thomson South-Western.

Nabi, G. \& Liñán, F. (2011). Graduate entrepreneurship in the developing world: intentions, education and development. Education \& Training, 53(5), 325-334.

Naffziger, D. W., Hornsby, J. S. \& Kuratko, D. F. (1994). A proposed research model of entrepreneurial motivation. Entrepreneurship Theory \& Practice, Spring, 29-42.

Rahman, H. \& Day, J. (2013).Who is your role model? The relationship between role models and student entrepreneurial motivation. Available at: http://sbaer.uca.edu/research/icsb/2012 /Rahman\%20142.pdf (accessed 19 March 2014).

Ramos-Rodríguez, A., Medina-Garrido, J., Lorenzo-Gómez, J. \& Ruiz-Navarro, J. (2010). What you know or who you know? The role of intellectual capital and social capital in opportunity recognition. International Small Business Journal, 28(6), 566-582. 
Renko, M., Kroeck, K. G. \& Bullough, A. (2012).Expectancy theory and nascent entrepreneurship. Small Business Economics, (39), 667-684.

Román, C., Congregado, E. \& Millán, J.M. (2013). Start-up incentives: Entrepreneurship policy or active labour market programme? Journal of Business Venturing, 28, 151-175.

Saeed, S., Yousafzai, S. Y., Yani-De-Soriano, M. \& Muffatto, M. (2013).The role of perceived university support in the formation of students' entrepreneurial intention. Journal of Small Business Management, doi: 10.1111/jsbm.12090.

Schjoedt, L. \& Shaver, K. G. (2007). Deciding on an entrepreneurial career: A test of the pull and push hypotheses using the panel study of entrepreneurial dynamics data. Entrepreneurship Theory and Practice, September, 733-751.

Schlaegel, C. \& Koenig, M. (2014). Determinants of entrepreneurial intent: A meta-analytic test and integration of competing models. Entrepreneurship Theory \& Practice, March, 291-332.

Sesen, H. (2013). Personality or environment? A comprehensive study on the entrepreneurial intentions of university students. Education \& Training, 55(7), 624-640.

Shane, S., Locke, E. A. \& Collins, C.J. (2003).Entrepreneurial motivation. Human Resource Management Review, 13, 257-279.

Shane, S. \& Venkataraman, S. (2000). The promise of entrepreneurship as a field of research. Academy of Management Review, 25(1), 217-226.

Shaver, K. G. \& Scott, L. R. (1991). Person, process, choice: The psychology of new venture creation. Entrepreneurship Theory \&Practice, Winter, 23-39.

Shook, C.L., Priem, R.L. \& McGee, J.E. (2003). Venture creation and the enterprising individual: A review and synthesis. Journal of Management, 29(3), 370-399.

Smith, K. \& Beasley, M. (2011). Graduate entrepreneurs: intentions, barriers and solutions. Education \& Training, 53(8/9), 722-740.

Solesvik, M. Z. (2013). Entrepreneurial motivations and intentions: investigating the role of education major. Education \&Training, 55(3), 253-271.

Spinelli, S. \& Adams, R. (2012).New venture creation-Entrepreneurship for the 21 ${ }^{\text {st }}$ century (9th ed.), New York: McGraw-Hill.

Sriram, V., Mersha, T. \& Herron, L. (2007). Drivers of urban entrepreneurship: An integrative model. International Journal of Entrepreneurial Behaviour \& Research, 13(4), 235-251.

Stephan, U. \& Uhlaner, L.M. (2010). Performance-based vs socially supportive culture: A cross-national study of descriptive norms and entrepreneurship. Journal of International Business Studies, 41, 1347-1364.

Taormina. R. J. \& Lao, S. K. (2007). Measuring Chinese entrepreneurial motivation-Personality and environmental variables. International Journal of Entrepreneurial Behaviour \& Research, 13(4), 200-221.

Townsend, D. M., Busenitz, L. W. \& Arthurs, J. D. (2010). To start or not to start: Outcome and ability expectations in the decision to start a new venture. Journal of Business Venturing, 25, 192-202.

Uygun, R. \& Kasimoglu, M. (2013). The emergence of entrepreneurial intentions in indigenous entrepreneurs: The role of personal background on the antecedents of intentions. International Journal of Business Management, 8(5), 24-40.

Vanevenhoven, J. \& Liguori, E. (2013). The impact of entrepreneurship education: Introducing the entrepreneurship education project. Journal of Small Business Management, 51(30), 315-328.

Vesalainen, J. \& Pihkala, T. (1999).Motivation structure and entrepreneurial intentions. Available at: http://fusionmx.babson.edu/entrep/fer/papers99/II/II_B/IIB\%20Text.htm (accessed 29 October 2012).

Wang, L., Prieto, L. \& Hinrichs, K. T. (2010).Direct and indirect effects of individual and environmental factors on motivation for self-employment. Journal of Developmental Entrepreneurship, 15(4), 481-502.

Wickham, P. A. (2006). Strategic entrepreneurship (4th ed.), England: Pearson Education.

Zanakis, S. H., Renko, M. \& Bullough, A. (2012). Nascent entrepreneurs and the transition to entrepreneurship: Why do people start new businesses? Journal of Developmental Entrepreneurship, 17(1), 1-25.

Zhang, Y., Duysters, G. \& Cloodt, M. (2013).The role of entrepreneurship education as a predictor of university students' entrepreneurial intention. International Entrepreneurship \& Management Journal, DOI 10.1007/s11365-012-0246-z.

Zhang, Y. \& Yang, J. (2006). New venture creation: Evidence from an investigation into Chinese entrepreneurship. Journal of Small Business \& Enterprise Development, 13(2), 161-173. 